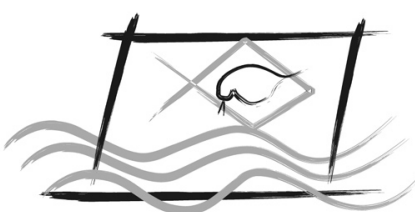

ECOTOX - BRASIL

\title{
Mercury distribution in muscular tissues of a tropical carnivorous fish (Hoplias malabaricus) from four lakes in the North of Rio de Janeiro State, SE Brazil
}

\author{
T.B. Jesus ${ }^{1}$; C.E.V. Carvalho ${ }^{2}$; A.G. Ferreira ${ }^{2}$; E.M. Siqueira ${ }^{2} \&$ A.L.S. Machado ${ }^{2}$ \\ 'Programa de Pós-Graduação Modelagem em Ciências da Terra e do Ambiente - PPGM Departamento de Ciências Exatas Universidade \\ Estadual de Feira de Santana, Avenida Transnordestina s/n, Campus Universitário, Módulo 5, sala MT 58, Bairro Novo Horizonte, CEP \\ 44.036.900 Feira de Santana - Bahia, Tel (75) 3224-8371 / Fax (75) 3224-8086. \\ ${ }^{2}$ Laboratório Ciências Ambientais, Centro de Biociências e Biotecnologia, Universidade Estadual do Norte Fluminense, Av. Alberto \\ Lamego 2000, Parque Califórnia, Campos dos Goytacazes, R.J.; CEP:28013-602; Brazil.
}

(Received March 19, 2010; Accept January 26, 2012)

\begin{abstract}
The purpose of this study is to determine the concentrations of total mercury in muscle of Hoplias malabaricus collected in lakes of the North Fluminense and bought in the Municipal Market (MM) since these lakes have suffered from the use of mercury fungicides in sugar cane plantations. The concentrations of mercury were measured by equipment ICP/AES with enhancement of cold vapor. The concentrations of $\mathrm{Hg}$ in the lake Campelo $\left(525.6 \mu \mathrm{g} \mathrm{kg}^{-1}\right)$ exceeded the concentrations of other lakes and fish of MM. An inverse correlation was observed between the concentrations of $\mathrm{Hg}$ and the standard length, weight and age in samples of fish from the Taquaruçu and Campelo lakes. Direct correlation between the concentrations of $\mathrm{Hg}$ and biological variables were observed for Feia lake, Cima lake and samples of MM.
\end{abstract}

Key words: Mercury, Lakes, Tropical fish and Biological variables.

Distribuição de mercúrio no tecido muscular em peixes tropicais carnívoros (Hoplias malabaricus) de quatro lagoas do Norte do Estado do Rio de Janeiro, Brasil

\section{RESUMO}

O objetivo do presente estudo é determinar as concentrações de mercúrio total em músculo de Hoplias malabaricus, coletados em lagoas do Norte Fluminense e adquiridos no Mercado Municipal (MM) uma vez que essas lagoas sofreram com a utilização de fungicidas mercuriais em plantações de cana-de-açúcar. As concentrações de mercúrio foram medidas através do equipamento ICP/AES com acessório de vapor frio. As concentrações de $\mathrm{Hg}$ na lagoa do Campelo $\left(525.6 \mu \mathrm{g} \mathrm{kg}^{-1}\right)$ superaram as concentrações das demais lagoas e dos peixes do MM. Uma correlação inversa foi observada entre as concentrações de Hg e o comprimento padrão, peso total e idade em amostras de peixes das lagoas de Taquaruçu e Campelo. Correlação direta entre as concentrações de $\mathrm{Hg}$ e variáveis biológicas foram observados para a lagoa Feia, lagoa de Cima e amostras do MM.

Palavras-chave: mercúrio, lagoas, peixe tropical e variáveis biológicas. 


\section{INTRODUCTION}

Due to its toxicity and the capacity to accumulate in aquatic organisms, mainly fish, mercury is considered an important contaminant; therefore it is one of the most studied metallic pollutants (Morel et al., 1998). Mercury behavior in biological systems is a matter of great concern due to its singular characteristics, such as: a) formation of covalent bonds with sulphydril groups from proteins $\left(\mathrm{SH}^{-}\right)$, inhibiting several enzymatic systems $\left(\mathrm{Hg}^{2+}\right)$; b) high affinity for blood cells and the central nervous system $\left(\mathrm{Hg}^{0}\right.$ and $\left.\mathrm{CH}^{3} \mathrm{Hg}\right)$; as well as, easiness to cross biological membranes.

The fish fauna is very sensible to environmental changes due to its more complex physiology when compared to other aquatic organisms. This characteristic makes them excellent indicators for environmental mercury bioavailability when compared to other organisms, such as mollusks and crustaceans (Paiva, 1989). Indeed several studies have already proved that teleosts are excellent organisms for studies monitoring the $\mathrm{Hg}$ bioavailability for human populations (Sellers et al., 1996; Bidone et al., 1997; Lacerda, 1997; Lebel et al., 1998; Kehrig et al., 1998).

$\mathrm{Hg}$ contamination in the North of Rio de Janeiro State is closely related to two main activities: a) the large use until the eighties of mercury fungicides in sugar cane plantations (probably the most important source); and the use of $\mathrm{Hg}$ in gold extraction activities in the Paraiba do Sul River Basin, between 1986-1987, which probably caused a significant impact, raising $\mathrm{Hg}$ levels in background sediments and aquatic biota (Lima, 1990; Câmara, 1990; Lacerda et al., 1993; Souza, 1994; Primo, et al., 2004).

\section{MATERIAL AND METHODS}

\section{Sampling area}

The lakes from the North of Rio de Janeiro State are important, mainly, for fishing and tourism activities, and, therefore, were selected for the present study. This region (Fig. 1) has an economy relying on sugar-cane monoculture, agriculture and cattle farming.

1) Taquaruçú Lake - nowadays is a very threatened ecosystem due to the urbanization of its margins and by the input of urban pollution. Its margins have progressively been occupied by illegal house constructions; witch dumps the sewage directly into the lake, without any treatment. According to Netto (1985), this lake also receives the influence of the surface runoff of Campos dos Goytacazes City.

2) Campelo Lake - located at the district of Campos dos Goytacazes, is close to the metropolitan area. Pasture and sugar-cane plantations surround the lake. This lake is an important fish source for the Campos dos Goytacazes Municipal Market (MM).

3) Cima Lake - located at $40 \mathrm{~km}$ from the coast of Campos dos Goytacazes. Cima Lake is an important tourist spot with large fish production. This lake receives the drainage of a well-preserved Atlantic Rain Forest.

4) Feia Lake - located between two cities (Campos and Quissamã), this lake is the largest freshwater lake of Brazil. Fish production is the main economical activity.

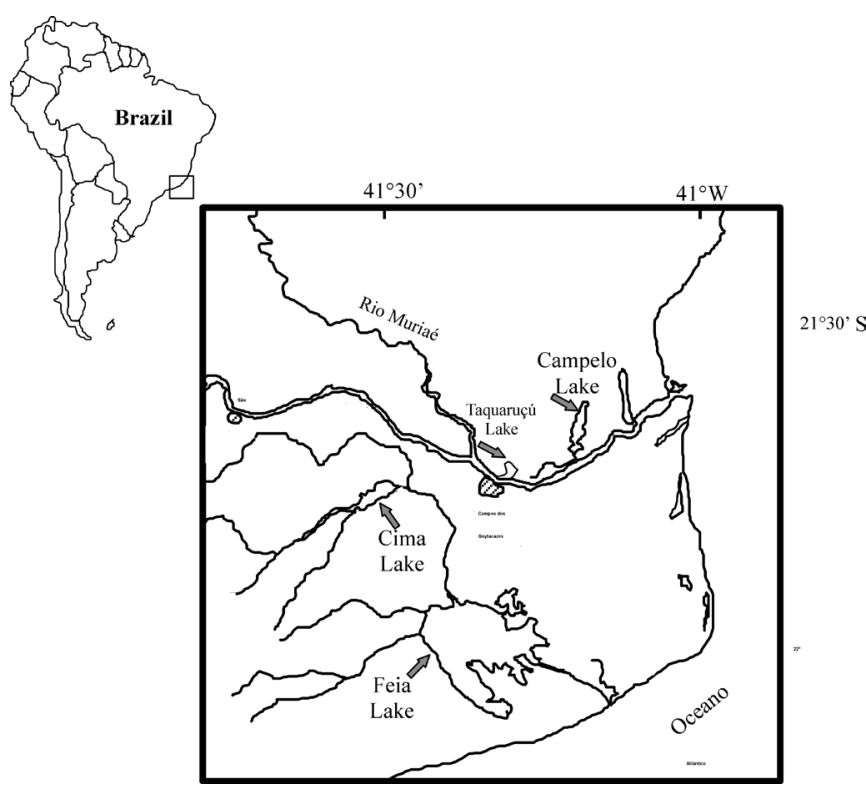

Figure 1 - Sampling sites location in Campos dos Goytacazes citie, Rio de Janeiro state, Brazil.

\section{Sampling strategies}

The organisms were sampled in two distinct periods, during the dry (from June to September) and wet (from November to March) seasons, through three types of sampling strategies: a) fish samples collected with the help of hooks and holding nets placed in the distinct lakes; b) fish samples bought at the local where they were fished; and c) samples bought at the Campos dos Goytacazes Municipal Market, the largest fish market in the region.

In the field the samples were identified and placed in plastic bags, then transported to the laboratory in ice boxes.

\section{Biological Parameters}

In the laboratory the specimens were measured (Standard Length), weighed and the sex was determined (macroscopic observation of the gonads). As a consequence of the quick sample preparation and the easy observation under a microscope, the counting of concentric growing rings of fish scale was chosen for age determination (Owens \& Pronin, 2000; Machias et al., 2002). Five fish scales of each specimen were taken from behind the chest fin (the use of scales from the fish lateral line was avoided), colored and observed under an optical microscope. The observation of each of the scales was individually performed by three distinct observers and an average of the counting was considered (the difference among the three observers was always less than $13 \%$ ). 
After the determination of the biological parameters the specimens were dissected and liver and muscle tissue samples were obtained for posterior mercury determination.

\section{Mercury determination}

The acid digestion used to solubilize the sample for mercury determination followed the methodology described by Bastos et al., (1997). Approximately $1.00 \mathrm{~g}$ of muscle was placed into an essay tube; then $1.0 \mathrm{~mL}$ of concentrated $\mathrm{H}_{2} \mathrm{O}_{2}$ and $3.0 \mathrm{ml}$ of $\mathrm{H}_{2} \mathrm{SO}_{4}: \mathrm{HNO}_{3}(1: 1)$ were added; after that, the tubes were placed in a block digestor $\left(60^{\circ} \mathrm{C} / 4 \mathrm{~h}\right)$; further, 5.0 $\mathrm{mL}$ of $5 \% \mathrm{KMnO}_{4}$ were added and the sample returned to the block digestor $\left(60^{\circ} \mathrm{C} / 30 \mathrm{~min}\right)$. Finally drops of $12 \% \mathrm{NH}_{4} \mathrm{OH}$. $\mathrm{HCl}$ were added. All mercury determinations were performed in an ICP-AES (Varian Liberty II) with cold generating accessory (CGA77).

All samples were analyzed for total mercury content in triplicates. Precision and accuracy tests were performed through the use of chemical blanks and the use of fish certified reference material DORM 1 (Squalus achantias muscle tissue) supplied by the Marine Analytical Chemistry Standards Programs, Canada.

\section{RESULTS}

\section{Biological parameters}

The standard length and the total weight were significantly higher $(p<0.05)$ for the individuals from the Cima Lake, when compared to the individuals from the Campelo Lake, even when the fishing effort is considered the same (Table 1).

When the variables were tested for correlation, the Spearman Correlation showed that the standard length positively varied with the total weight of the sampled fish from both lakes $(\mathrm{p}<0.05)$ (Table 2$)$.

As a whole, the average standard length varied according to the following tendency: MM > Cima Lake $>$ Feia Lake $>$ Taquaruçú lake $>$ Campelo lake. The Mann Whitney U-Test $(\mathrm{p}<0.05)$ demonstrated that the fish from the Campelo Lake were significantly smaller than the fish from the other sites. The opposite was observed for the fish from the MM which

Table 1 - Average (and interval) of standard length, total weight, age and mercury concentration in Hoplias malabaricus from Campelo and Cima lake.

\begin{tabular}{lcccc}
\hline Lake & $\begin{array}{c}\text { Standard Lenght } \\
(\mathbf{m m})\end{array}$ & $\begin{array}{c}\text { Total Weight } \\
(\mathbf{g})\end{array}$ & $\begin{array}{c}\text { Age } \\
(\text { years })\end{array}$ & $\begin{array}{c}\mathbf{H g} \\
\left(\boldsymbol{\mu} \mathbf{g ~ k g}^{-1}\right)\end{array}$ \\
\hline \multirow{2}{*}{ Campelo } & 226.0 & 272.0 & 5 & 525.6 \\
& $(180.0-348.0)$ & $(120.0-725.0)$ & & $(73.50-1365)$ \\
Cima & 260.0 & 428,0 & 5 & 56,00 \\
& $(152.0-395.0)$ & $(175.0-1400)$ & & $(50.90-345.4)$ \\
\hline
\end{tabular}

presented the highest values for the standard length $(\mathrm{p}<0.05)$. The fish from the Cima, Feia and Taquaruçú lakes did not differ significantly in standard length (Table 3).

Similar to the observed for the standard length, the total weight of the fish from the MM and from the Campelo lake were the highest and the lowest, respectively $(\mathrm{MM}>$ Feia Lake $>$ Cima Lake $>$ Taquaruçú lake $>$ Campelo lake). The fish from the Campelo Lake were significantly smaller than the ones from the MM, Cima Lake and Feia Lake. The same was observed for the fish from the Taquaruçú lake. The fish from the MM were significantly bigger than the others but the fish caught at the Feia Lake.

When the average age of specimens was evaluated for each sampling site, the result showed that the fish from the $\mathrm{MM}$ and Feia Lake were the oldest ones, and significantly differed from the fish of the other locations $(\mathrm{p}<0.05)$. The fish from Cima Lake were classified as the youngest ones, though no statistic difference was observed in relation to Campelo Lake or Taquaruçú Lake.

The Spearman Correlation was significant $(p<0.05)$ between the standard length and the total weight of the fish for specimens from all of the sampling sites. These same parameters when analyzed in relation to the age were not significant.

As a whole, the fish from the Campelo Lake presented an average mercury concentration of 3.78 times superior to the ones found in fish from the Cima Lake. The variance analysis (Mann-Whitney U-test) showed a significant difference in the mercury concentration among the sampling sites $(\mathrm{p}<0.05)$.

Table 2 - Average of standard length, total weight, age and individuals numbers from all studied sites.

\begin{tabular}{lcccc}
\hline Lake & N & $\begin{array}{c}\text { Standart } \\
\text { length }(\mathbf{m m})\end{array}$ & $\begin{array}{c}\text { Total } \\
\text { weigth }(\mathrm{g})\end{array}$ & $\begin{array}{c}\text { Age } \\
\text { (years) }\end{array}$ \\
\hline Campelo Lake & 28 & $226 \pm 41.2$ & $272 \pm 138$ & $5.00 \pm 1.12$ \\
Cima Lake & 20 & $260 \pm 51.0$ & $428 \pm 263$ & $4.63 \pm 1.12$ \\
Feia Lake & 28 & $254 \pm 32.9$ & $445 \pm 184$ & $6.56 \pm 1.23$ \\
Taquaruçú Lake & 24 & $249 \pm 42.5$ & $325 \pm 205$ & $5.00 \pm 1.24$ \\
Municipal Market (MM) & 30 & $281 \pm 27.2$ & $487 \pm 143$ & $7.00 \pm 0.76$ \\
\hline
\end{tabular}

Table 3 - Mercury concentration (wet weight average in $\mu \mathrm{g} \mathrm{kg}^{-1}$ ) in muscle tissue of Hoplias malabaricus from different lakes of the North Region of the Rio de Janeiro State and of the Paraíba do Sul and Tapajós River.

\begin{tabular}{lccc}
\hline Sampling Site & $\mathrm{N}$ & $\mathrm{Hg}\left(\mu \mathrm{g} \mathrm{kg}^{-1}\right)$ & Observations \\
\hline Campelo Lake & 28 & 525.6 & Present study \\
Feia Lake & 28 & 171.6 & Ferreira et al., (2003) \\
Cima Lake & 20 & 138.9 & Presente estudo \\
Taquaruçú Lake & 28 & 76.90 & Ferreira et al., (2003) \\
MM* $^{*}$ & 28 & 73.30 & Ferreira et al., (2003) \\
Tapajós River & 4 & 620.0 & Bidone et al., (1997) \\
Paraíba do Sul River & - & 370.0 & Lacerda et al., (1990) \\
Paraíba do Sul River & - & 87.00 & Mandarino et al., (2000) \\
- & - & 500 & Not predator fish \\
& - & 1000 & (ANVISA/98) \\
- & - & 500 & Predator fish (ANVISA/98) \\
- & * Campos dos Goytacazes Municipal Market
\end{tabular}


The standard length and total weight did not show significant correlation with the mercury concentration for any of the lakes. In the Campelo Lake, the relation between mercury concentration Vs standard length and total weight was inversed, while in the Cima Lake, the opposite was observed.

\section{DISCUSSION}

The Cima Lake is characterized as a well preserved aquatic ecosystem, free of anthropic contamination with heavy metals (Ferreira, 1997). Studies of Primo (2000) and Lima et al., (2000) mention this water body, mainly in its initial part, close to the Urubu and Imbé rivers, as a lake with many fish species, including Hoplias malabaricus, due to the intense aquatic vegetation present in it. This vegetation would be serving as shelter and hunting zone for Hoplias malabaricus, which finds favorable conditions to its development, despite the over fishing described by Bizerril and Bidegain (2002). This fact favors the growth and weight gain of the "Traíra" of the Cima Lake when compared to the ones from the Campelo Lake.

The fish from the Campelo Lake were the oldest ones, although no significant difference was observed among the sampling sites. In a study performed by Domingues et al., (1998) the positive correlation between age and standard length or total weight were described. The present study reinforces that fact, though the statistic analysis was not significant (Spearman Correlation). Domingues et al., (1998) also mention that, in natural environments, the occurrence of individuals of the same age with different lengths is common, and associated this fact to the natural pressures of competition, predation, food availability, and abiotic conditions to which the organisms are exposed.

In relation to the total mercury concentrations, determinated for the individuals from the different sampling sites, the lowest average concentration of this metal was observed for the specimens caught in the Cima lake, when compared to the result found for the fish of the Campelo Lake. This fact may be a result of the preserved state and the absence of anthropic contamination with heavy metals previously mentioned (Ferreira, 1997). Besides that, this lake is part of a closed system, linked to the Ururaí and Urubu Rivers and also the Feia Lake. Therefore, there is a greater income of water to this Lake characterizing it as a more dynamic environment than the Campelo Lake. This last factor might contribute to a shorter retention time for mercury in the Cima Lake. Souza (2000) suggests that the $\mathrm{Hg}$ of the Cima Lake might be carried through the Ururai channel to the Feia Lake, where high levels of $\mathrm{Hg}$ were found in the sediment. Such observations are possible explanations for the lower mercury concentration found in fish originated from the Cima Lake in comparison to the ones from the Campelo Lake.

The high concentrations found in the specimens caught in the Campelo Lake (average $=525.6 \mu \mathrm{g} \mathrm{kg}^{-1}$ ) can be justified by the feeding habit of "Traíra", which is a carnivorous fish, with tendencies to accumulate mercury in its tissues (Mandarino et al., 2000). This fact confirms the hypothesis of environmental contamination by mercury in the Cima Lake, described Sousa (2000) and Ferreira et al., (2003). Another hypothesis, which might corroborate the $\mathrm{Hg}$ bioavailability, would be the reduced water renovation that takes place in that lake, due to the obstruction of the Cataia Channel, its main source of water. In that way, it would be expected an increase in the residence time of water in the lake, favoring methylation processes in the sediment, and, as a consequence, the transeference of $\mathrm{Hg}$ to the fish fauna of the lake, mainly "lambaris" (Astyanax bimaculatus) and "saírús" (Cyphocarax gilbert), core food sources of "traíra".

The high concentrations of $\mathrm{Hg}$ in the muscle tissue of Hoplias malabaricus might be associated with the high concentrations found by Primo (2000), in the superficial sediment of the Campelo Lake (349.6 $\left.\mu \mathrm{g} \mathrm{kg}^{-1}\right)$. These values may also be related to the location of the lake, close to the metropolitan region of Campos dos Goytacazes, surrounded by sugar-cane plantations, in use or abandoned, in which mercurial fungicides have been broadly used (Câmara, 1990), to the mercury originated from the atmosphere, or to the fluvial transport to the coastal areas of the continent (Hanten et al., 1998; Pinho, 1998). Following that idea, the mercury from the soil might have been carried off by the rain and deposited on the sediment of the lake. In sediment, mainly, the demethylation $\left(\mathrm{Me}_{2} \mathrm{Hg}\right)$ and methylation $\left(\mathrm{MeHg}^{+}\right)$processes are enhanced by the anaerobical condition and the presence of sulfate-reducing bacteria (Azevedo, 2003); Hacon et al. 1996; Ferreira et al., 2003; Ferreira et al., 2004). Therefore, the $\mathrm{MeHg}^{+}$is released to the water column and enters to the food chain, reaching high concentration in top-predator fish (Hirokatsu, 2000).

Lima et al., (2000) studying the mercury contamination of five carnivorous, three herbivorous and one omnivorous fish species in the Tapajós River, at an important gold mining region of Pará, found the highest average concentrations in two of the five carnivorous species, Cichla sp. (Tucunaré) and Serrasalmus nattereri (Piranha). The average concentrations were $\left(306.1 \mu \mathrm{g} \mathrm{kg}^{-1}\right)$ and $\left(280.4 \mu \mathrm{g} \mathrm{kg}^{-1}\right)$, respectively. In the present study, the average mercury concentration found in the muscle tissue of fish from the Campelo Lake, was, approximately, 2.4 times higher than the value observed by that author $\left(222.1 \mu \mathrm{g} \mathrm{kg}^{-1}\right)$. The fact that different mercury concentrations were observed for species with the same feeding habit may be associated with many factors, like the different diet of the species, according to the Codex Committee about Fish and its Derivations (Brasil, 1975). We can also take into consideration the different habitats of the species, the Campelo Lake is a lentic environment without constant renovation of its water, while the Tapajós River is very large and much more dynamic. Finally, the "Tucunaré" is a very long an heavy species, different from the individuals of "Traíra" sampled in the present work, which had their sizes narrowed to the size allowed by net. Lacerda and Salomons (1991) reported that larger and heavier individuals tend to accumulate higher concentrations of $\mathrm{Hg}$ when compared to smaller ones. 
Bidone et al., (1997) studying the mercury concentration in fish from the Tapajós River, an area under strong impact of mercury originated from the extraction of gold (Table 2), observed mercury concentrations very close to the ones found in the present study.

Ferreira et al., (2004) studying the mercury concentration in a predator marine fish species (Carcharhinus signatus), found a high average concentration of mercury in the muscle tissues of this species, and associated their results to the process of biomagnification. The present study corroborates that finding, once a top-level predator was used to determinate total mercury.

As it was mentioned before, since the mercury excretion is very slow, larger and older individuals of the population will probably present higher $\mathrm{Hg}$ concentrations (Lacerda \& Salomons, 1991).The results found for the Cima Lake confirm that hypothesis. However, for the individuals from the Campelo Lake, this tendency could not be confirmed. Hoslsbeek et al., (1997) reported inversed correlation between the $\mathrm{Hg}$ concentration and the length or age of indian planktivorous fish species, and associated their results to processes of dimethylation of methyl-mercury in the muscle tissue of the analyzed fish species.

Making a comparison between the present data and the ones obtained by Al-Hashimi et al., (1991), it was possible to confirm that top predator fish present higher $\mathrm{Hg}$ concentrations than the fish at the base of the food web, as a consequence of the biomagnification. The organisms from the Campelo Lake presented the highest total mercury concentrations in its tissues, which corroborates the hypothesis. On the other hand, they also presented the shortest lengths and smallest weights, which could be explained through the standardization of the capture technique, where fish were selected according to the size of the net.

The fish captured in the Cima Lake presented an average concentration lower than the ones recommended by the Agência Nacional de Vigilância Sanitária (ANVISA), which defines as the highest level for human consumption 0.5 and $1.0 \mu \mathrm{g} \mathrm{kg}^{-1}$ for non-predator fish and predator fish, respectively (ANVISA, 1998).

The specimens from the Cima Lake, had an average concentration of $525.6 \mu \mathrm{g} \mathrm{kg}^{-1}$ wet weight. This concentration is above the highest levels determinated by the World Health Organization (WHO, 2003). However, the Agência Nacional de Vigilância Sanitária (ANVISA, 1998) draws different levels for non-predator and predator fish (Tab. 2). Therefore, according to the Brazilian Laws, the $\mathrm{Hg}$ concentration in muscle tissue of $H$. malabaricus from the Campelo Lake is under the maximum established limit.

In order to evaluate the degree of transference of $\mathrm{Hg}$ from the "Traíra" of the Campelo Lake and the human population, the rate of $\mathrm{Hg}$ ingestion for chronic exposure was calculated (USEPA, 1995; Hacon et al., 1997a,b). For this calculation a human being of $70 \mathrm{~kg}$, based on the data of Azevedo \& Chasin (2003), and a daily ingestion of $0.1 \mathrm{~kg}$ of fish were considered.

\section{$\operatorname{Tin}=\mathbf{H g} \times \mathbf{T i} / \mathbf{P c}$}

$\mathrm{Tin}=$ Rate of $\mathrm{Hg}$ Incorporation $\left(\mathrm{mg} \mathrm{kg}^{-1}\right.$ day)

$\mathrm{Hg}=\mathrm{Hg}$ concentration in the muscle tissue $\left(\mathrm{mg} \mathrm{kg}^{-1}\right)$

$\mathrm{T} \mathrm{i}=$ Ingestion rate ( $\mathrm{kg}$ of ingested fish)

$\mathrm{Pc}=$ Weight of the person $(\mathrm{kg})$

The daily ingestion of $0.1 \mathrm{~kg}$ of muscle tissue of Hoplias malabaricus from the Cima Lake, represents a Rate of $\mathrm{Hg}$ incorporation of $0.75 \mu \mathrm{g} \mathrm{kg}^{-1}$ day. This value is 2.5 times higher than the reference dose for chronic incorporation, which is 0.3 $\mu \mathrm{g} \mathrm{kg}^{-1}$ day per body weight as described in USEPA (1995).

\section{CONCLUSION}

The specimens of Hoplias malabaricus from the Cima Lake presented an average $\mathrm{Hg}$ concentration of $56.0 \mu \mathrm{g} \mathrm{kg}^{-1}$, which is lower than the maximum dose for fish consumption recommended by the Agência Nacional de Vigilância Sanitária (ANVISA) that is $1000 \mu \mathrm{g} \mathrm{kg}^{-1}$. The same concentration is lower than the chronic incorporation limit for Mercury determined by the USEPA, which is $0.3 \mu \mathrm{g} \mathrm{kg}^{-1}$. Therefore, the ingestion of this fish do does not offer risk to the human health. On the other hand, specimens of $H$. malabaricus from the Campelo Lake presented higher $\mathrm{Hg}$ values $\left(525.6 \mu \mathrm{g} \mathrm{kg}^{-1}\right)$ than the ones established by the World Health Organization (WHO), which is $500 \mu \mathrm{g} \mathrm{kg}^{-1}$. Besides that, that value is above the $\mathrm{Hg}$ chronic incorporation limit determined by the USEPA. Although the values are below the maximum dose of mercury incorporation through the consumption of fish, according to the ANVISA, the results obtained in the present study suggest that the ingestion of $H$. malabaricus for long periods of time is not recommended, because it may cause serious toxic risks to the human population as a consequence of the biomagnification process.

\section{REFERENCES}

AL-HASHIMI, A.H. \& AL-ZORBA, M.A., 1991, Mercury in some commercial fish from Kuwait: a pilot study. Sci. Total Environ., 106: 71-82.doi: 10.1016/0048-9697(91)90021-6.

MINISTÉRIODA SAÚDE, Agência Nacional de Vigilância Sanitária. Portaria ${ }^{\circ}$ 685, de 27 de agosto de 1998 - Princípios gerais para o estabelecimento de níveis máximos de contaminantes químicos em alimentos. Disponível em: http://www.anvisa.gov.br/legis/ portarias/685 98.htm. Acessado em: 02/02/2009.

AZEVEDO, F.A. \& CHASIN, A.A.M., 2003, As Bases Ecotoxicológicas da Ecotoxicologia. São Paulo: RiMa Editora, 322p.

AZEVEDO, F.A. \& CHASIN, A.A.M., 2003, Metais - Gerenciamento da toxicidade Ed.Atheneu/InterTox - São Paulo, SP, Brasil $554 \mathrm{p}$.

BASTOS, W.R.; MALM, O.; PFEIFFER, W.C. \& CLEARY, D., 1998, Establishment and Analytical Quality Control of Laboratories for $\mathrm{Hg}$ Determination in Biological and Geological Samples in the Amazon, Brazil. Cien. Cult., 50 (4): 255-260.

BIDONE, E.D.; CASTILHOS, Z.C.; CID de SOUZA, T.M. \& LACERDA, L.D., 1997, Fish contamination and human exposure to mercury in the Tapajos river basin, Para State, Amazon, Brazil: 
A screening approach. Bull. Environ. Contam. Toxicol., 59:194201. doi: 10.1007/BF02409640.

BIDEGAIN, P.; BIZERRIL, C. \& SOFFIATI, A., 2002, Lagoas do Norte Fluminense: perfil ambiental. Rio de Janeiro, Fundação Superintendência Estadual de Rios e Lagoas (SERLA), 148 p. (Boletim 14).

BRASIL., 1975, Ministério da saúde, Resolução No 18/75 da Comissão Nacional de Normas e Padrões para alimentos. Diário Oficial da União, 9 de Dezembro 1975.

CÂMARA, V.M., 1990, O caso de Campos - RJ Estudos do quadro de morbilidade causado pela exposição pregressa dos trabalhadores aos fungicidas organo-mercuriais. In: Riscos e Conseqüências do Uso do Mercúrio. Seminário Nacional. FINEP/CNPq/MS/ IBAMA, Rio de Janeiro p. 229-246.

FERREIRA, A.G.; MELO, E.J.T. \& CARVALHO, C.E.V., 2003, Histological aspects of mercury contamination in muscular and hepatic tissue of Hoplias malabaricus (PISCES, ERYTHRINIDAE) of Campelo Lagoon, North of Rio de Janeiro State, Brazil. Acta Microsc., 12 (01):49-54.

FERREIRA, A.G.; FARIA, V.V.; CARVALHO, C.E.V.; LESSA, R.P. \& SANTANA, F.M., 2004, Total mercury in the night shark, Carcharhinus signatus, in the western equatorial atlantic ocean. Braz. Arch. Biol. Technol., 47(4): 629-634. doi: 10.1590/ S1516-89132004000400016.

HACON, S., 1996, Exposição ao mercúrio da populacão humana de Alta Floresta, Mato Grosso. Ph.D. Thesis, Universidade Federal Fluminense, Niterói, 134p.

HACON, S.; ROCHEDO, E.R.; CAMPOS, R.; ROSALES. G. \& LACERDA, L.D., 1997a, Risk assessment of mercury in Alta Floresta. Amazon Basin Brazil. Water Air Soil Poll., 97:91-105. doi:10.1016/S0375-6742(96)00066-0.

HACON, S., 1997b, Avaliação do risco potencial para a saúde humana na exposição ao mercúrio na área urbana de Alta Floresta. MT Bacia Amazônica-Brasil. Tese de Doutorado, Niterói: Programa de Pós-graduação em Geoquímica, Universidade Federal Fluminense.

HOLSBEEK, L.; DAS, H.K. \& JOIRIS, C.R., 1997, Mercury speciation and accumulation in Bangladesh freshwater and anadromous fish. Sci. Total Environ., 198: 201-210. doi:10.1016/ S0048-9697(97)05453-3.

KEHRIG, H.A.; MALM, O.; AKAGI, A.; GUIMARÃES, J.R.D. \& TORRES, J.P.M., 1998, Methylmercury in fish and hair samples from the Balbina Reservoir, Brazilian Amazon. Environ. Res., 77: 84-90. doi:10.1006/enrs.1998.3836.

LACERDA, L.D. \& SALOMONS, W., 1991, Mercury in the Amazon: A chemical time-bomb? Dutch Ministry of Housing, Planning and Environment, Haren.

LACERDA, L.D.; CARVALHO, C.E.V.; REZENDE, C.E. \&
PFEIFFER, W.C., 1993, Mercury in sediments of the Paraíba do Sul River Continental Shelf, S. E. Brazil. Mar. Poll. Bull., 26 (4): 220-222. doi:10.1016/0025-326X(93)90626-U.

LACERDA, L.D. \& MARINS, R.V., 1997, Anthropogenic mercury emissions to the atmosphere in Brazil: The impact of gold mining. J. Geochem. Explor., 58 (2-3):223-229. doi:10.1016/ S0375-6742(96)00068-4.

LEBEL, J.; MERGLER, D.; BRANCHES, F.; LUCOTTE, M.; AMORIM, M.; LARIBE, F. \& DOLBEC, J., 1998, Neurotoxic Effects of Low-Level Methylmercury Contamination in the Amazonian Basin. Environ. Res., section A, 79(1): 20-32. doi:10.1006/enrs.1998.3846.

LIMA, E.C.R., 1990, Riscos e conseqüências do uso do mercúrio: A situação do Rio de Janeiro In: Riscos e Conseqüencias do uso do mercúrio. FINEP/CNPq/MS/IBAMA, Rio de Janeiro, p: 268 -274.

MACHIAS, A.; SOMARAKIS, S. \& TSIMENIDES, N., 1998, Bathymetric distribution and movements of red mullet Mullus surmuletus. Mar. Ecol. Prog. Ser., 166: 247-257.

MANDARINO, M.; MÁRSICO, E.T.; SANTOS, N.N.; SÃO CLEMENTE, S.C. \& JUNIOR, A.J.P., 2000, Determinação do Grau de Contaminação Mercurial na Musculatura de Hoplias malabaricus (Traíra), Loricariichthys sp (Cascudo) e Rhamdia $s p$ (Bagre), Coletados no Rio Paraíba do Sul, Estado do Rio de Janeiro, Brasil. Arquivos da Faculdade de Veterinária da UFRGS, Porto Alegre, 28 (1): 79 - 88.

MOREL, F.M.; KRAEPIEL, A.M.L. \& AMYOT, M., 1998, The chemical cycle and bioaccumulation of mercury. Annu. rev. ecol. syst., (29): 543-566. doi: 10.1146/annurev.ecolsys.29.1.543.

PRIMO, W.S., 2000, Distribuição de mercúrio e carbono orgânico em solos e sedimentos da região Norte do Estado do Rio de Janeiro. Tese de mestrado, Universidade Estadual do Norte Fluminense, Campos dos Goytacazes, Brazil.

PRIMO, W.S.; CARVALHO, C.E.V.; CALASANS, C.V.C. \& SUZUKI, M.S., 2004, Mercury and Organic Carbon Distribution in Six Lakes from the North of Rio de Janeiro State. Braz. Arch. Biol. Technol., 47(1): 139-145.

SELLERS, P.; KELLY, C.A. \& RUDD, J., 1996, Photodegradation of methyl mercury in lakes, Nature, 380: 694-697. doi:10.1038/380694a0.

SOUZA, C.M.M., 1994, Avaliação ambiental dos riscos do mercúrio em áreas de garimpo de Brasil. Tese de Doutorado, Universidade Federal do Rio de Janeiro, Rio de Janeiro, Brasil.

USEPA, Human health evaluation manual (part A). In: Risk assessment guidance for Superfund, v.1. Washington, DC: US Environmental Protection Agency, 1989. EPA/540/1-89/002.

WORLD HEALTH ORGANIZATION, 1989, Mercuryenvironmental aspects, [Environmental Health Criteria, 86]. Geneve, 115. 